\title{
EDITORIAL
}

\section{The continuing challenge of air pollution}

\author{
B. Brunekreef
}

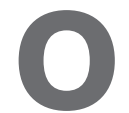
nce a severe but local problem of highly industrialised and densely populated cities, air pollution has now morphed into a more insidious threat to the public health of entire nations. Smoke from domestic coal fires, power plants and heavy industry has largely vanished from our skies. This has been achieved through the use of clean fuels, filtration of flue gases, improvements in process technology, and export of the most polluting industries to countries with lower wages and less pollution control. At the same time, motor vehicle transport has increased enormously and other sources of air pollution, such as intensive livestock farming, have emerged. Pollution is transported over long distances and secondary pollutants such as ozone are formed through photochemical reactions. The erstwhile distinctions between "dirty" cities and the "clean" countryside have become blurred as a result, and nowadays a much larger fraction of the population is exposed to some form or level of hazardous air pollution than $50 \mathrm{yrs}$ ago. Because air pollution, in some ways, is now less visible and less immediately irritating than it used to be, understanding and communicating the health risks of air pollution has become more of a challenge than it used to be.

Members of the European Respiratory Society (ERS) Environment Committee have now produced a booklet on air pollution and health that is an elegant attempt to explain to a wide audience what air pollution is in the current day and age, and what damage it still does to our health [1]. The authors have found a welcome mix of scientific authority and clarity, which will appeal to clinicians, public health practitioners, patient organisations, stakeholder representatives and informed members of the lay public.

One reason why it so important to have an accessible booklet on air pollution and health is that pollution levels in many areas in Europe are still far above what the World Health Organization (WHO) considers acceptable in its latest revision of the Air Quality Guidelines [2]. It has been difficult for the air pollution scientific community to weigh in sufficiently when decisions about new limit values were made in Europe in 2008. As a result, Europe now accepts air pollution concentrations that are much higher than the WHO Air Quality Guidelines, but also considerably higher than the Air Quality Standards of the US Environmental Protection Agency (EPA) [3, 4]. One can speculate about why we have less stringent guidelines on air pollution in Europe than we should have. Well-organised business-interest groups put pressure on policy makers to

CORRESPONDENCE: B. Brunekreef, Institute for Risk Assessment Sciences and Julius Center for Health Sciences and Primary Care, University Medical Center Utrecht, Utrecht University, Utrecht, P0 Box 80176, 3508TD, The Netherlands. E-mail: b.brunekreef@uu.nl consider carefully economic interests in all areas of decision making; it has been argued that the interests of the environment and of public health are less well taken care of in the process [5]. We could also learn from experiences in areas such as the fight for smoke-free indoor spaces. There is a very long history of attempts to make indoor spaces free from tobacco smoke and the role of the tobacco industry in obstructing such attempts is well documented [6]. The lessons learned in that area of public health science and policy need to be taken to heart by the outdoor air pollution community as well, especially: 1) to keep studying the issue even after abatement measures have been taken, as documentation of benefits is important and it helps to keep the issue on the agenda just in case laws or measures are being challenged; 2) to support studies at a local level which may not be scientifically "new" but will help inform local or national policy makers in their decisions; 3) to interact with other disciplines to get the questions framed correctly; 4) to be prepared to deal with strong, interest-driven opposition and to work with advocacy organisations at the forefront of the policy debate; and 5) to train young scientists in the field to work with policy makers and advocacy groups.

In the meantime, evidence is strengthening that reductions of air pollution actually make a public health difference. Public health benefits from smaller scale interventions, such as a ban on coal sales in Dublin (Ireland) [7] and lowering the sulfur content of fuels in Hong Kong (China) [8], have been documented previously. Recently, it was shown that differential reductions in particulate matter pollution across the USA were associated with differential increases in life expectancy [9]. Such studies offer encouragement to continue the quest for cleaner air. Booklets such as the one now produced by the ERS Environment and Health Committee offer welcome ammunition for those engaged in the struggle for healthier air. The ERS would do well to cherish the voluntary, free contributions of the experts involved.

\section{STATEMENT OF INTEREST}

A statement of interest for the author of this manuscript can be found at www.erj.ersjournals.com $/ \mathrm{misc} / \mathrm{statements.dtl}$

\section{REFERENCES}

1 Künzli N, Perez L, Rapp R. Air Quality and Health. Lausanne, ERS, 2010.

2 World Health Organization. WHO Air quality guidelines for particulate matter, ozone, nitrogen dioxide and sulfur dioxide. Global Update 2005. http://whqlibdoc.who.int/hq/2006/WHO_ SDE_PHE_OEH_06.02_eng.pdf Date last updated 2005.

3 Brunekreef B, Maynard RL. A note on the 2008 EU standards for particulate matter. Atmos Environ 2008; 42: 6425-6430. 
4 Annesi-Maesano I, Forastiere F, Kunzli N, et al. Particulate matter, science and EU policy. Eur Respir J 2007; 29: 428-431.

5 Smith KE, Fooks G, Collin J, et al. Is the increasing policy use of Impact Assessment in Europe likely to undermine efforts to achieve healthy public policy? J Epidemiol Community Health, 2010; 64 478-487.

6 Widome R, Samet JM, Hiatt RA, et al. Science, prudence, and politics: the case of smoke-free indoor spaces. Ann Epidemiol 2010; 20: 428-435.
7 Clancy L, Goodman P, Sinclair H, et al. Effect of air-pollution control on death rates in Dublin, Ireland: an intervention study. Lancet 2002; 360: $1210-1214$

8 Hedley AJ, Wong CM, Thach TQ, et al. Cardiorespiratory and allcause mortality after restrictions on sulphur content of fuel in Hong Kong: an intervention study. Lancet 2002; 360: 1646-1652.

9 Pope CA III, Ezzati M, Dockery DW. Fine-particulate air pollution and life expectancy in the United States. N Engl J Med 2009; 360: 376-386. 